Stanisław Sorys

(i) https://orcid.org/oooo-0002-1277-6493

Uniwersytet Papieski Jana Pawła II w Krakowie

\title{
Ewolucja więzi społecznych
}

(doi) https://doi.org/Io.15633/9788374389839.OI

Więzi społeczne sięgają najdawniejszych czasów, chociaż zdefiniowano je naukowo znacznie później i sformułowano szereg ich teorii, odnoszących się do ich powstawania, funkcjonalności, potrzeb i oczekiwań jednostki. Podstawowym warunkiem identyfikacji jednostki z grupą (termin identyfikacja używany w socjologii amerykańskiej) jest aprobująca świadomość przynależności do tej, a nie innej grupy. Dla niektórych socjologów ważnym czynnikiem więzi, który decyduje o istnieniu grupy, jest świadomość wspólnego stosunku do przedmiotów, symboli, wartości, norm czy osób.

Więzi społeczne ujawniają się w grupie, ona je kształtuje, kreuje postawy i zachowania swych członków, poglądy i przekonania, wyznacza ramy określonego stylu życia. Więź powstała i podtrzymywana w grupie wyrasta na kanwie najistotniejszych potrzeb jednostki oraz potrzeb międzyludzkich. Jednostka może realizować się w grupie, a grupa staje się jej zapleczem w dużej części emocjonalnym, poznawczym, kulturowym.

Zależności osobiste czy zachodzące w obrębie danej zbiorowości mogą mieć odniesienie do świadomego i subiektywnego działania w określonym celu. Mogą mieć także charakter wielokierunkowy, bardzo różnorodny, jednostkowy i częściowy, uświadamiany lub nie, bezpośredni („twarzą w twarz") lub pośredni (np. z udziałem mass mediów). Uczestnictwo jednostki w grupie i nawiązanie z nią więzi jest jej wewnętrznym nakazem, wypływającym z potrzeby przebywania $z$ innymi, realizacji wspólnych celów i uczestnictwa w życiu społecznym, samorealizacji, zapewnienia sobie i innym ochrony itp. Może być czasowe lub trwałe, bardziej lub mniej angażujące i satysfakcjonujące. Niezależnie od przyjętych kryteriów grupa jest zawsze oparciem dla jednostki, obszarem, w którym może bezpiecznie funkcjonować i realizować się, a także zdobywać życiowe doświadczenie. 


\section{Grupa społeczna - ujęcie definicyjne i istota}

Grupą ludzi nazywa się zbiór osób mających jakąś wspólną cechę lub przypadkowo znajdujących się w tym samym miejscu czy podejmujących jedną czynność w tym samym miejscu i w tym samym czasie. Jednak należy uściślić, iż taka grupa osób, która nie współdziała ze sobą, jest określana mianem grupy niespołecznej. Grupą społeczną nazywa się grupę osób, w której dwie lub więcej osób współpracuje ze sobą oraz są one od siebie zależne w zakresie zaspokajania potrzeb i osiąganiu celów.

Rodzi się natomiast pytanie, od ilu ludzi zaczyna się grupa społeczna. Jedni twierdzą, że od dwóch, inni, że od trzech. Więcej argumentów przemawia za ostatnią z tych opcji. Zbiór trzech osób stanowi bardziej skomplikowaną i dynamiczną całość niż dwie osoby. Każda z osób może bowiem ustosunkowywać się do każdej z pozostałych dwóch, jak również do tego, co dzieje się między nimi - co je łączy bądź dzieli. Wśród trzech osób mogą powstawać zmienne sojusze dwu osób przeciwstawiających się trzeciej.

Grupę charakteryzują typowe elementy, do których zalicza się: wielkość, pełnione role, status, relacje interpersonalne, spójność (rozumiana jako więź łącząca członków grupy), interakcje, zadania, zmiany okresowe i normy ${ }^{1}$.

Pojęcie grupy społecznej pojawiło się w wyniku zaistnienia potrzeby szerszej analizy nowoczesnych społeczeństw, jak i rozszerzania się socjologicznej problematyki mającej zastosowanie do zjawisk różnej skali, wszelkich zespołów ludzkich warunkujących owe zjawiska. Grupa społeczna okazała się terminem ogólnym, rozumianym bardzo szeroko. Obejmował on: klasę społeczną, zbiorowość religijną, rodzinę, wspólnotę wiejską, stowarzyszenia sportowe, partię polityczną, grupę zawodową, klub towarzyski, także plemię pierwotne, jak również naród nowoczesny, klasę szkolną. Była to jakaś zbiorowość ludzka, mała lub wielka, którą można spotkać w życiu. Tak rozległe rozumienie grupy społecznej występowało nie tylko w socjologii polskiej, ale i w całej socjologii. Konsekwencją tego była z jednej strony trudność dotycząca zbudowania trafnej definicji grupy, z drugiej powstanie potrzeby porządkowania tych zróżnicowanych 
tworów społecznych. Według definicji Albiona W. Smalla, przyjętej potem przez Stanisława Ossowskiego, grupą jest „zbiór osób, które możemy ujmować jako całość ze względu na jakiekolwiek godne uwagi stosunki zachodzące pomiędzy jego członkami" ${ }^{2}$. Z czasem przestano się zajmować wielością i rozbudowywanymi ustawicznie klasyfikacjami grup, a zaczęto koncentrować na tym, co się dzieje wewnątrz grup małych, postrzeganych jako ministruktury społeczne. Wszystkie grupy są zbiorowościami, ale takimi, które spełniają warunki interakcji jej członków. Oznacza to, że grupy te mają poczucie moralnego zobowiązania co do wypełniania oczekiwań związanych z ich rolą społeczną. W przypadku grupy wskazuje się na czynniki subiektywne, do których należy: poczucie bycia grupą, postrzeganie siebie w kategorii „my”, a także uznawanie tych samych wartości, podobny stosunek do tych samych symboli, przejawianie tych samych postaw. Interakcje zachodzące między członkami grupy oraz poczucie wspólnoty wyraźnie odróżniają grupę społeczną od przypadkowego zbioru jednostek. Oprócz interakcji, uznawania wspólnych wartości i świadomości bycia wspólnotą istotnym czynnikiem dodatkowym jest wewnętrzne ustrukturyzowanie grupy. Składają się na nie „trwałe wzory” w grupie, powiązanie pozycji i ról w grupie. Grupa społeczna wymusza na swych członkach częstotliwość, kierunek oraz treść interakcji, w jakie oni wchodzą. Równie ważne są procesy samookreślania, jak i powstawania świadomości bycia grupą. Są one traktowane jako wtórne w stosunku do wewnętrznych struktur grupy, które determinują, kontrolują i niejako wymuszają świadomość bycia grupą przez większość jej członków. Tak postrzegana grupa społeczna ujmowana jest jako samoistna całość, nie podlegająca redukcji, samodzielna, autonomiczna. Grupa społeczna tworzy zewnętrzną - w stosunku do jednostek - rzeczywistość i wywiera na nie rozmaite naciski oraz stosuje wobec nich różnego rodzaju formy przymusu. Przymus i siła oddziaływania stanowią najistotniejsze cechy wszelkich zjawisk płynących z ukształtowania struktur grupy, nie zaś z dobrej woli jej członków. Do struktur wewnątrzgrupowych zalicza się:

- strukturę socjometryczną - wzajemne oddziaływania między ludźmi, relacje interpersonalne;

2 B. Szacka, Wprowadzenie do socjologii, Oficyna Naukowa, Warszawa 2008, s. 188. 
- $\quad$ strukturę przywództwa - to, w jaki sposób i w wyniku czego członkowie grupy uzyskują władze nad innymi, w jaki sposób ją sprawują, jakie są skutki różnych stylów sprawowania władzy;

- strukturę komunikowania - modele komunikacji, zwłaszcza w przypadku cech roli przywódcy - interakcji przywódcy z pozostałymi członkami grupy;

- spójność grupy - brak wewnętrznych podziałów, podgrup, klik, przejawianie takich samych wartości, postaw, uznawanie takich samych norm, wzorów zachowań oraz wspólne działanie ${ }^{3}$.

Istotną cechą grupy - oprócz jej struktur wewnątrzgrupowych - jest to, że grupa wytwarza własne wartości, wzory zachowań i reguły postępowania, których uznawanie i przestrzeganie obowiązuje jej członków.

\section{Ustanawianie więzi społecznych}

Nawiązywanie i utrzymywanie przyjacielskich związków z innymi ludźmi jest jednym z głównych celów zachowań społecznych. Mając obok siebie innych ludzi, możemy osiągać rzeczy, których nigdy nie zdołalibyśmy osiągnąć, działając w pojedynkę. Dotyczy to spraw zarówno osobistych, jak i społecznych. Chęć nawiązania więzi społecznych przejawia się w różnych formach. Ludziom przyświecają różne cele, m.in. to, żeby być lubianym przez innych, akceptowanym, docenianym, sprostać wymaganiom innych osób, mieć przyjaciół, uzyskiwać wsparcie społeczne, mieć dostęp do informacji, zdobyć wyższą pozycję społeczną, dokonywać wymiany korzyści materialnych itp. Lista przedstawionych celów wskazuje na różne intencje zachowań społecznych, motywacje ich podejmowania, niekiedy ich współzależności ${ }^{4}$.

Chęć rozumienia siebie i innych sprowadza się najczęściej do formułowania opinii, ocen, wartościowania. W zachodzących reakcjach społecznych trudno się nie zastanawiać, kim są inni jej uczestnicy, co robią i myślą o nas i czego od nas oczekują. Natomiast w przypadku chęci uzyskania lub uporządkowania informacji społecznych zwraca się uwagę na postawy,

3 B. Szacka, Wprowadzenie do socjologii, dz. cyt., s. 192-196.

4 D. T. Kenrick, S. L. Neuberg, R. B. Cialdini, Psychologia społeczna, Gdańskie Wydawnictwo Psychologiczne, Gdańsk 2001, s. 712-713. 
przyjaźnie, uprzedzenia, bronienie własnego wyobrażenia o sobie, czasami uzyskanie szczegółowego i dokładnego obrazu samego siebie i innych. Istotne jest tu także pragnienie kształtowania własnego „ja” w kontekście prezentowanych postaw, autoprezentacji, oddziaływań społecznych, zachowań prospołecznych, także uprzedzeń. Bywa, że człowiek zmuszony jest bronić poczucia własnej wartości, godności. Obrona siebie i tych, których cenimy, realizowana jest najczęściej w grupie, która wspiera te dążenia ${ }^{5}$.

Tworzenie więzi społecznych, otwiera drogę do realizacji wybranych celów. Więzi społeczne mają istotne znaczenie dla każdego. Służą m.in. zrozumieniu siebie i innych, zdobyciu i utrzymaniu pozycji, przyciągnięciu i utrzymaniu partnera/partnerki oraz obrony siebie i swych sojuszników. Mark Leary uznał, że więzi społeczne stanowią podstawę osiągnięcia innego ważnego celu, którym jest podtrzymanie wysokiej samooceny. Przeprowadzone przez niego badania potwierdziły hipotezę, że poczucie własnej wartości jest socjometrem i waha się w zależności od tego, czy dany człowiek czuje się akceptowany, czy odrzucony przez innych ${ }^{6}$.

Więź społeczna w socjologii pojmowana jest w sposób niejednolity. Jan Szczepański przez wieź społeczną rozumie „zorganizowany system stosunków, instytucji i środków kontroli społecznej, skupiający jednostki, podgrupy i inne elementy składowe w funkcjonalną całość zdolną do utrzymania się i rozwoju"7.

Więź społeczna w ujęciu definicyjnym Maksymiliana Pacholskiego to „ogół reakcji i wzajemnych oddziaływań międzyosobowych i międzygrupowych w obrębie zbiorowości, siły podtrzymujące te relacje i oddziaływania oraz współwystępująca z nimi świadomość identyfikacji i łączności"8.

Z kolei Stanisław Ossowski więź społeczną utożsamia z czynnikami subiektywnymi, psychicznymi, nie negując jednakże czynników obiektywnych. Według niego więź psychiczna to „aprobująca świadomość przynależności do grupy, tendencja do zachowywania najważniejszych konformizmów grupowych, kult wspólnych wartości, świadomość wspólnych

\footnotetext{
5 D. T. Kenrick, S. L. Neuberg, R. B. Cialdini, Psychologia społeczna, dz. cyt., s. 713.

6 D. T. Kenrick, S. L. Neuberg, R. B. Cialdini, Psychologia społeczna, dz. cyt., s. 712-713.

7 B. Szacka, Wprowadzenie do socjologii, dz. cyt., s. 196.

8 M. Pachcholski, Stownik pojęć socjologicznych, Wydawnictwo Akademii Ekonomicznej w Krakowie, Kraków 1997, s. 204.
} 
interesów, ale i gotowość do przedkładania interesów grupy ponad interesy osobiste, jeśli taki konflikt zajdzie, albo przynajmniej przekonanie, że powinno się interesy grupy przedkładać nad swoje [...] świadomość wspólnego stosunku do pewnych symboli, przedmiotów i osób"9.

Więź społeczna przejawia się w dwóch aspektach: obiektywnym i subiektywnym. Obiektywny - odzwierciedla „dające się rzeczowo określić wspólności i związki międzyludzkie”, subiektywny przedstawia stany świadomości, do których zalicza się postawy wobec innych i całej zbiorowości oraz wynikające $\mathrm{z}$ tego działania ${ }^{10}$.

Nawiązując do koncepcji Emila Durkheima (solidarność mechaniczna i solidarność organiczna) i Ferdinanda Tönniesa, można powiedzieć, że więź społeczna kształtuje się w rezultacie podobieństwa zachowań wewnątrz zbiorowości, jak również w rezultacie zróżnicowania dopełniających się działań. Więzi znajdują odzwierciedlenie w dwóch odmiennych stanach świadomości. Sytuacjom podobieństwa odpowiada spontaniczność i dodatnie emocje. Więź rozumiana jako realizacja odmiennych, ale dopełniających się ról - uświadamiana jako dana z natury lub przez ustanowienie i przeżywana niekiedy jako przykra konieczność - jest umacniana przez racjonalizacje i moralne uzasadnienie ${ }^{11}$.

Więź społeczna obejmuje dwa zakresy spraw, które ludzi łączą i jednoczą. Są to:

- wspólnota potrzeb i systemów wartości, na podłożu której pojawiają się podobne dążenia i działania;

- różnice w zakresie dyspozycji indywidualnych i położenia społecznego oraz zróżnicowania zadań jednostek i grup w podziale pracy wraz z odpowiadającym mu systemem stratyfikacji; na tym gruncie kształtują się pozycje i role społeczne, tworzy się sieć powiazań i zależności między ludźmi ${ }^{12}$.

Więź społeczna oznacza świadomość przynależności do grupy lub zachowywania najważniejszych konformizmów grupowych. Można ją określić także jako kult wspólnych wartości i interesów lub całość stosunków i zależności zachodzących między ludźmi. Ma charakter zróżnicowany,

9 B. Szacka, Wprowadzenie do socjologii, dz. cyt., s. 196.

10 M. Pacholski, Stownik pojęć socjologicznych, dz. cyt., s. 204.

11 M. Pacholski, Stownik pojęć socjologicznych, dz. cyt., s. 204-205.

12 M. Pacholski, Stownik pojęć socjologicznych, dz. cyt., s. 205. 
„stopniowalny”, kształtujący się na wielu płaszczyznach i w wielu kierun$\mathrm{kach}^{13}$.

Wobec powyższego można uznać, iż więź społeczna tworzy się i utrzymuje przez to, co ludzi łączy, jak i dzieli w zbiorowym współżyciu. Jest to „ogół stosunków, relacji i zależności wiążących jednostkę z grupą, zbiorowością, ośrodkami kontroli społecznej lub inną jednostką. Opiera się przede wszystkim na świadomości przynależności do grupy, wspólnocie wartości i interesów, przedkładania interesów grupy nad swoje własne, identyfikacji działań i przekonań z działaniami i przekonaniami grupy, co jest efektem podzielania podstawowych konformizmów grupy"14.

\section{Więź społeczna a spójność grupy}

Więź społeczna oparta jest na spójności grupy, która uzależniona jest od wielorakości czynników spajających ludzi i grupy. Każda grupa posiada pewien stopień spójności; jest to stopień, w jakim grupa „trzyma się razem”. Stanowi on wypadkową wszystkich działających na członków grupy sił, które skłaniają ich do pozostawania w grupie. Z punktu widzenia jednostki wyszczególnia się dwa rodzaje motywacji skłaniających ludzi do bycia razem i do wspólnego podejmowania różnych działań. Z jednej strony jest to wzajemna atrakcyjność członków, z drugiej korzyści i satysfakcja wynikające $\mathrm{z}$ członkostwa $\mathrm{w}$ grupie. W każdej grupie, niezależnie od jej charakteru, zaznacza się skłonność do wzmacniania tej spójności. Do tego przyczyniają się wytwarzające się w grupie specyficzne obyczaje, systemy wartości wewnątrzgrupowych, specyficzny, właściwy tylko członkom grupy sposób komunikowania się ${ }^{15}$.

Silna spójność powoduje dominację grupy nad swymi członkami. Wraz ze wzrostem spójności wzrasta skłonność, a także możliwość kontrolowania członków przez grupę. Natężenie presji grupy wobec jej członków zależy od zaznaczającego się pomiędzy nimi układu sił. W przypadku gdy

13 A. Batko, Społeczeństwo od A do Z, Wydawnictwo „Zamiast korepetycji”, Kraków 1997, s. 228.

14 K. Olechnicki, P. Załęcki, Słownik socjologiczny, Wydawnictwo Graffiti вс, Toruń 2004, s. 244 .

15 B. Szacka, Wprowadzenie do socjologii, dz. cyt., s. 196. 
grupie będzie bardziej zależało na swych członkach lub jej członkom na grupie, zaznaczy się większy nacisk grupy na jednostkę celem jej podporządkowania się normom grupowym. Natomiast, gdy jednostka jest mniej pewna własnej pozycji w grupie, tym bardziej może obawiać się braku akceptacji, a nawet wykluczenia. To z kolei prowadzi do zachowań konformistycznych. Do takich zachowań nie jest skłonna jednostka pewna zarówno swojej pozycji w grupie, jak i pełnej akceptacji w grupie, chociaż nie oznacza to, że tak właśnie czyni ${ }^{16}$.

Można mówić o bezpiecznym poziomie spójności grupy, którego przekroczenie zazwyczaj przynosi negatywne skutki. Jednym z nich jest dezindywidualizacja jednostki i uznanie grupy za wartość najwyższą, a także utożsamianie się z nią aż do zatraty własnej tożsamości, a nawet do utraty instynktu samozachowawczego. Do innych skutków mogących mieć negatywne konsekwencje zalicza tzw. system myślenia grupowego. Jednostka czuje się „zrośnięta” z grupą do tego stopnia, iż nie kwestionuje głoszonych w grupie poglądów ani trafności podejmowanych decyzji, ignoruje także docierające do niej informacje podważające te decyzje, jak również te, które wskazują na inne - lepsze niż przyjęte w grupie - rozwiązania ${ }^{17}$.

Więzi społeczne mają odniesienie do ludności, która jest członkiem jakiejś zbiorowości. Niniejsza zbiorowość, jest więc zbiorem ludzi podobnych pod względem cech społecznie doniosłych w danym miejscu i w danym czasie, także ze względu na sytuację życiową, interesy czy szanse. Wyszczególnia się:

- więź obiektywną, określającą w obiektywnym ujęciu wspólnotę sytuacji życiowej; czynnikami generującymi tę więź są: płeć, wiek, rasa, obywatelstwo, teren zamieszkania, rodzaj pracy itp., także przeżywanie pewnych emocji (satysfakcji lub frustracji, dumy lub wstydu z własnej sytuacji, sympatii lub wrogości, zawiści bądź uznania, repulsji lub tolerancji wobec innych itp.), wytworzonych stereotypów, myślenia w kategoriach „swoi” i „obcy”, „nasi” i „tamci”, „my” i „oni”; wspólnej sytuacji życiowej towarzyszy samoświadomość lub tożsamość zbiorowa; 
- więź subiektywną, stanowiącą odzwierciedlenie jakichś warunków obiektywnych, w których żyje zbiorowość lub jakichś cech obiektywnych jej członków, wynikających m.in. z zamieszkiwania w podobnych warunkach (np. na wsi, w mieście), sytuacji ekonomicznej zbiorowości (np. bieda, bogactwo), wykonywanego zawodu (np. adwokaci, lekarze), wieku (np. młodzież, nastolatki, emeryci); wspólnoty przekonań, wierzeń, wartości, światopoglądu;

- więź moralną, będącą szczególną relacją do innych, objętych kategorią „my”, opartą o trzy podstawowe składniki: zaufanie, lojalność i solidarność; granice kategorii „my” mogą być wyznaczone węziej lub szerzej, a intensywność, jak i zasięg więzi moralnej są zmienne ${ }^{18}$.

W grupie odbywa się socjalizacja jednostki. Przebiega ona różnymi ścieżkami, często może być nawet przerwana. Do procesów konstytuujących grupę zalicza się:

- ocenę - oferta grupy, dostrzeżenie jej plusów i minusów (kompetencje i właściwości danej osoby, dopasowanie się do danej grupy);

- zaangażowanie - „stałość deklaracji uczestnictwa”, gotowość jednostki do poświecenia na rzecz grupy własnych zasobów, takich jak: czas, pieniądze lub wysiłek ${ }^{19}$.

Następnie jest wybór grupy - tzw. badanie, jednostka nie jest związana z żadną grupą i poznaje różne alternatywne grupy, potem następuje przyłączenie się do grupy, inicjacja, odnajdywanie niszy (poznanie grupy: wtajemniczenie w sekrety grupy, akceptacja jej założeń i sposobu działania), podjęcie nowych ról i ich odgrywanie oraz negocjacja roli, z czasem może pojawiać się osłabienie więzi (przemijanie zaangażowania i fascynacji grupą lub/i jej uczestnikami) prowadzące nieuchronnie do odejścia z grupy ${ }^{20}$.

\section{Etapy tworzenia się więzi społecznych}

Prapoczątkiem więzi społecznych są styczności przestrzenne, bezpośrednie i pośrednie, zachodzące między ludźmi w określonych zbiorowościach społecznych. Odziaływania te mogą mieć różny charakter i znaczenie,

18 P. Sztompka, Socjologia, Wydawnictwo Znak, Warszawa 2004, s. 184-187.

19 C.K. Oyster, Grupy, dz. cyt., s. 97-98.

20 C.K. Oyster, Grupy, dz. cyt., s. 99-103. 
w zależności od: kontekstu społecznego, zasięgu, powiązań z układami ekonomicznymi, politycznymi, kulturalnymi, psychicznymi, etycznymi ${ }^{21}$.

Więzi społeczne tworzyły się stopniowo. Przechodziły od form pierwotnych, naturalnych, do bardziej złożonych, przemyślanych i funkcjonalnych, zwanych wtórnymi. Jest to najprostsza typologia, powstała na zasadzie przeciwstawienia, wywodząca się od jednego z twórców socjologii amerykańskiej Charlesa H. Cooleya. Według niego istnieją takie grupy, które mają charakter uniwersalny, a spotkać je można w każdym społeczeństwie, zarówno prymitywnym, egzotycznym, jak i cywilizowanym, przede wszystkim zaś w doświadczeniu życiowym każdego człowieka. Cooley przez grupy pierwotne rozumiał „grupy odznaczające się ścisłym zespoleniem jednostek poprzez stosunki osobowe”; wyróżnił też pięć cech grupy pierwotnej: względna trwałość, bezpośrednie kontakty, mała liczebność, niewyspecjalizowany charakter kontaktów, względna zażyłość uczestników”22. Zwrócił uwagę na to, że nie wszystkie z tych cech decydują w różnym stopniu o specyfice grupy. Względna trwałość to cecha właściwa dla wszystkich grup. Jest warunkiem uznania jakiejś zbiorowości za grupę. Dwie kolejne cechy są ściśle ze sobą powiązane, gdyż bezpośrednie kontakty są typowe dla grup o małej liczebności, a mała liczebność z kolei prowadzi do bezpośrednich kontaktów. O szczególnym charakterze grupy pierwotnej decydują niewyspecjalizowany charakter kontaktów i względna zażyłość jej członków. Niewyspecjalizowany charakter oznacza, że ważniejsze są kontakty z drugą osobą niż sama płaszczyzna tych kontaktów, bo może być ona za każdym razem inna. W takich warunkach wytwarza się zażyłość łącząca grupę. W grupie pierwotnej członków łączą przede wszystkim stosunki osobowe, a nie rzeczowe. Stosunki osobowe są relacjami zachodzącymi między osobami i są celem samym w sobie. Druga osoba stanowi wartość autoteliczną. Stosunki osobowe stanowią przeciwieństwo stosunków rzeczowych, gdyż tam zachodzą stosunki pomiędzy rolami społecznymi sprowadzające się nie do tego, jaką ktoś rolę pełni, ale jak ją pełni. Panujące w grupach pierwotnych zażyłe stosunki osobowe i niewyspecjalizowane kontakty powodują, że ich uczestnicy zaspokajają podstawowe potrzeby emocjonalne i psychiczne. Przynależność do nich

21 A. Batko, Społeczeństwo od A do Z, dz. cyt., s. 228.

22 Cyt. za: J. Szacki, Historia myśli socjologicznej, Państwowe Wydawnictwo Naukowe, Warszawa 2002, s. 560 . 
daje poczucie bezpieczeństwa, bycie lubianym, akceptowanym, wyzwala dobre samopoczucie. Grupy pierwotne „Zakotwiczają nas w społeczeństwie", chronią przed poczuciem zagrożenia, samotnością ${ }^{23}$.

Taką grupą uniwersalną o znaczeniu podstawowym jest rodzina. Wiąże się to $\mathrm{z}$ biologicznymi właściwościami gatunku ludzkiego. Każdy człowiek rodzi się w rodzinie, wyrasta w rodzinie, w niej też dochodzi do dojrzałości i samodzielności, a potem sam zakłada rodzinę. Człowiek w zasadzie przez cały czas funkcjonuje w kręgu rodziny, stąd ona jest mu najbliższa. Ma ona charakter naturalny, spontaniczny ${ }^{24}$.

Rodzina stanowi fundamentalny, konstruktywny element każdego społeczeństwa, stanowiąc jego podstawowy budulec. Społeczeństwo składa się z rodzin. Socjologowie definiują rodzinę jako pierwszą i zarazem uniwersalną instytucję społeczną, utrwaloną $\mathrm{w}$ tradycji wszystkich kultur, cechującą się zrytualizowanym zespołem działań ludzkich ukierunkowanych na zaspokajanie istotnych potrzeb swych członków (przede wszystkim seksualnych, prokreacyjnych, socjalizacyjnych). Rodzina traktowana jest jako podstawowa komórka społeczna - społeczeństwo składa się z rodzin, tak jak każde ciało składa się z komórek ${ }^{25}$.

Drugą grupą uniwersalną wymienioną przez Cooleya jest grupa sąsiedzka. Podstawę stanowi stwierdzenie, że każdy gdzieś mieszka i styka się w miejscu zamieszkania z innymi ludźmi. Jest to sąsiedztwo czy wspólnota lokalna. Dziecko w okresie dorastania wchodzi w kontakty spontaniczne, nieformalne, najpierw w kontakty społeczne $\mathrm{z}$ innymi dziećmi, potem $\mathrm{w}$ kręgi koleżeńskie, a następnie $\mathrm{z}$ upływem lat poszerza je o kręgi przyjacielskie, towarzyskie osób dojrzałych. Prospołeczne towarzyskie skłonności człowieka są naturalne, uniwersalne, bo zauważalne „od zawsze". Pozwalają człowiekowi na osobiste znajomości oraz intymne, bliskie relacje „twarzą w twarz”. Są one stosunkowo trwałe, a w przypadku rodziny najtrwalsze i dla członków rodziny znaczące. Obejmują one różne przejawy działalności, są wielofunkcyjne, angażują również szeroki zakres życia jednostek. Mają charakter w pewnym stopniu totalitarny, a według określenia Levisa A. Cosera - „żarłoczny”, bo kontrolują i normują działalność swych członków. Na ogół są przedmiotem silnych, pozytywnych

23 B. Szacka, Wprowadzenie do socjologii, dz. cyt., s. 199-20o.

24 B. Szacka, Wprowadzenie do socjologii, dz. cyt., s. 219.

25 T. Szendlak, Socjologia rodziny, Wydawnictwo Naukowe PWN, Warszawa 2010, s. 95. 
identyfikacji, solidarności, zaufania i lojalności. Przynależność do nich jest ważnym elementem tożsamości jednostki ${ }^{26}$.

Na dwoistość życia społecznego ludzi, znajdującą wyraz w świecie intymnym, prywatnym i osobistym oraz $\mathrm{w}$ świecie publicznym, sformalizowanym i zdepersonalizowanym zwrócił uwagę jeszcze przed Cooleyem niemiecki socjolog Ferdinand Töennies w słynnej książce Wspólnota i spoteczeństwo. Jego rozważania miały charakter historyczny. Wyszczególnił on tradycyjne społeczeństwa ludzkie - plemienne, pierwotne, żyjące w ramach silnych, zwartych, terytorialnie określonych wspólnot cechujących się wysokim stopniem spoistości, integracji, wartości i przekonań. Te formy bytowania określił mianem Gemeinschaft jako właściwe gatunkowi ludzkiemu, pomiędzy którymi zachodzą stosunki oparte na „woli naturalnej”. Więzi łączące tę wspólnotę oparte były na wrodzonej sympatii do innych ludzi, tendencji dośrodkowej, prospołecznej. W terminologii Toenniesa społeczeństwo nowoczesne, zurbanizowane i zindustrializowane prowadzi do zautomizowania się wspólnot, tworzy masy żyjące na własną rękę, egoistyczne, kierujące się czystym wyrachowaniem. Jest to społeczeństwo samotnych jednostek. Ludzie tworzący grupy społeczne traktują je instrumentalnie, kierując się wyłącznie własnymi korzyściami z przynależności do nich. Ich racja sprowadza się do posiadania czegoś konkretnego, a nie samej satysfakcji z uczestnictwa w grupie. Zaznaczyć należy, że w wielu przypadkach uczestnictwo nie sprowadza się do osiągania satysfakcji, lecz podyktowane jest życiową koniecznością ${ }^{27}$.

Grupy pierwotne odnajdujemy w każdym społeczeństwie, są właściwe dla każdej jednostki. Wiążą się bezpośrednio z jej doświadczeniem życiowym. Każdy człowiek styka się z nimi zawsze, potem dopiero dochodzi do kontaktów z innymi grupami, np. edukacyjnymi, religijnymi, zawodowymi itp. Grupy pierwotne mają charakter socjalizacyjny, bo stanowią pierwsze agendy, za pomocą których społeczeństwo dociera do jednostek. Grupy te, zwłaszcza rodzina, kształtują jednostkę na tyle mocno, że w pewnym sensie uodparniają ją na późniejsze korekty i modyfikacje. Nazywanie tych grup pierwotnymi wiąże się także z tym, że traktowane są przez ludzi jako wyjątkowo ważne, bo dotyczące kwestii szczególnych,

26 P. Sztompka, Socjologia, dz. cyt., s. 220.

27 P. Sztompka, Socjologia, dz. cyt., s. 221. 
identyfikacji terenu, gdzie jednostki znajdują oparcie emocjonalne oraz ważne wskazówki do definiowania własnej tożsamości ${ }^{28}$.

Małe grupy pierwotne pośredniczą w komunikowaniu się jednostki na poziomie mikrostruktury życia społecznego. Działają z jednej strony jako przekaźnik, z drugiej jako filtr komunikatów płynących z poziomu mikrostrukturalnego. Na drodze od nadawcy do odbiorców, którymi są jednostki, znajduje się „modyfikator w postaci siatki grup pierwotnych"29. Grupy pierwotne są najbardziej rozpowszechnione w społeczeństwie. Stanowią naturalne i najbliższe środowisko człowieka. Opierają się na kontaktach bezpośrednich. Przez tysiąclecia były formą organizacji społecznej zapewniającej gatunkowi ludzkiemu przetrwanie.

Badający społeczeństwa pierwotne William Graham Summer wprowadził pojęcie grupy własnej i obcej. Spostrzegł, że jednostki mają odmienny stosunek do zbiorowości własnej i obcej, czyli zewnętrznej. Zaznaczył, iż członków zbiorowości własnej cechują wzajemne stosunki pokoju, porządku, prawa, rządu i gospodarności, a tych samych członków do ludzi spoza grupy cechuje zazwyczaj poczucie wrogości, pogardy, nienawiści „braterstwo wewnątrz - wojna na zewnątrz”, chyba że stosunki na zewnątrz zmienią umowy. Odmienny stosunek do grupy własnej i obcej nie jest wyłącznie cechą grupy pierwotnej, ale czymś powszechnym w społeczeństwie. Nie zawsze jednak przybiera drastyczną postać, opisywaną przez Summera. Jednym z przejawów odmiennego postrzegania grupy własnej i obcej jest kierowanie się stereotypami. Grupę własną postrzega się jako bardziej zróżnicowaną i zindywidualizowaną niż grupę obcą. W odniesieniu do grupy własnej zapamiętuje się zachowania pozytywne, a do grupy obcej - złe, negatywne, przykre. Zachowania pozytywne członków grupy obcej tłumaczy się najczęściej niezależną od niej sytuacją zewnętrzną, a negatywne - nieakceptowalnym charakterem jej członków. To odwrotnie niż w przypadku grupy własnej. W grupie własnej powodów zachowań negatywnych doszukuje się z koniecznościach wynikających z sytuacji zewnętrznej, a pozytywnych - w szlachetnym charakterze jej członków. Niemniej jednak jest bardzo trudno określić, czy grupa, w której ludzie uczestniczą, jest grupą własną czy obcą. Z jednej strony grupy

28 P. Sztompka, Socjologia, dz. cyt., s. 220.

29 J. Szmatka, Małe struktury społeczne. Wstęp do mikrosocjologii strukturalnej, $\mathrm{pw}$, Warszawa 2007 , s. 238. 
własne cechuje silna więź wewnętrzna i silna wrogość wobec grup innych, z drugiej - postawy i zachowania charakterystyczne dla grupy własnej łatwo wywoływać. Stosując określenia grupa własna - grupa obca, zaznacza się podział na „my” i „wy”, „swoi” i „obcy”. Grupę własną postrzega się zawsze w kategoriach „my”30.

Grupy wtórne stanowią przeciwieństwo grup pierwotnych. Nie spełniają bowiem warunków grupy pierwotnej. Są na ogół bardziej liczebne, mniej spontaniczne i interesowne oraz mocniej sformalizowane. Obejmują kontakty i interakcje pośrednie, bardziej wyspecjalizowane. W ich obrębie jednostki zachowują większą anonimowość. Grupy te dopuszczają głębokie różnice w wartościach i postawach swych członków. Grupami wtórnymi są środowiska zawodowe, grupy zadaniowe, stowarzyszenia celowe lub grupy zorganizowane różnego typu, czego przykładem są organizacje społeczne.

Zróżnicowanie grup pod względem wielkości oddziałuje na jej inne cechy. Grupy pierwotne są małe, zwarte i oparte na bliskich, osobistych kontaktach, zaś grupy wtórne są większe i bardziej bezosobowe. Grupy w tórne wskazują na szersze uczestnictwo jednostek w strukturze społecznej, polegające przede wszystkim na zajmowaniu określonej pozycji w grupie. Przykładowo: grupa seminaryjna, grupa przyjaciół z akademika oraz inne grupy funkcjonujące w uczelni umiejscowione są szerzej w strukturze tej placówki. Związane są z większą strukturą uczelni i zarazem włączają uczestników grup w coraz to większe struktury. Są one także terenem, $\mathrm{w}$ którym zachodzą interakcje $\mathrm{z}$ racji zajmowania pozycji $\mathrm{w}$ grupie, pełnienia w niej różnych ról, co prowadzi do tworzenia, utrwalania a nawet zmiany symboli kulturowych, które kierują postępowaniem i służą jako kryteria do oceny siebie i innych ${ }^{31}$.

Współczesne społeczeństwo jest zdominowane przez grupy wtórne. Są one postrzegane w sposób bezosobowy, w dużym stopniu przez pryzmat pewnej interesowności, np. pieniądza, interesów korporacyjnych, wielkiej polityki. O losach ludzkich, zdaniem Stanisława Osiatyńskiego, decyduje pewien układ abstrakcyjnych sił i poczucie bezsilności jednostki. Autor określa to terminem „kompleks liliputa”. W grupach wtórnych pojawia się

30 P. Sztompka, Socjologia, dz. cyt., s. 202.

31 J.H. Turner, Socjologia. Koncepcje i zastosowanie, Zysk i S-ka Wydawnictwo, Poznań 1998, s. $55-56$. 
dążenie ludzi do odnowienia grup pierwotnych. Znajduje to wyraz w tworzeniu i rozprzestrzenianiu się grup zbliżonych do pierwotnych, chociaż wykraczających poza przyjęty katalog Cooleya. Są to grupy resocjalizacyjne, rehabilitacyjne, grupy terapeutyczne różnego typu: treningu osobowościowego, psychoanalizy zbiorowej, grupowych konsultacji przedmałżeńskich. Powstanie i funkcjonowanie tych grup wyraża pragnienia człowieka, by doświadczyć bliskich, interpersonalnych kontaktów z innymi, zaznać szczerości, otwartości wobec innych, bezinteresowności, czyli praktycznie wszystkiego tego, czego im brakuje w życiu zawodowym czy oficjalnym. Przejawem tego jest m.in. pojawienie się w środowisku młodzieżowym sekt czy grup quasi-religijnych, dostarczających substytutów rodzinnej lub przyjacielskiej bliskości ${ }^{32}$.

Turner podaje, iż wiele grup znajduje się gdzieś pośrodku między pierwotnymi a wtórnymi. Są to najczęściej grupy niewielkie pod względem liczby, w przypadku których zaznacza się dążenie do bycia grupą pierwotną. Często jednak dążenie to ustaje z braku czasu albo z powodu określonych działań danej grupy, takich jak: rywalizacja, popularność czy osiągnięcia. Socjologia nie stworzyła nazwy dla tej grupy. Zaznaczyć należy, że wielkość grupy niszczy zwykle możliwość większej bliskości jednostki, a tym samym ogranicza wykrystalizowanie się silnych, spójnych więzi opartych na poczuciu bliskości i intymności ${ }^{33}$.

\section{Wpływ grupy na jednostkę ze względu na więzi społeczne}

Więzi społeczne utrzymujące się w grupach mają istotny wpływ na oddziaływanie grup na jednostkę. Im bardziej grupa jest pierwotna, tym większe ma możliwości w zakresie oddziaływania. Jednym z nich jest wpływ na wyobrażenie jednostki o sobie, ponieważ widzi ona własne odbicie w gustach innych, którzy są dla niej ważni. Wpływom podlegają także wartości i przekonania, gdyż ujawnia się skłonność do przyjmowania kulturowych symboli ważnych dla grupy, z którą się utożsamia i z którą łączone jest jej

32 P. Sztompka, Socjologia, dz. cyt., s. 220-221.

33 J.H. Turner, Socjologia. Koncepcje i zastosowanie, dz. cyt., s. 94-95. 
wyobrażenie o sobie. Innym przedmiotem oddziaływania grupy jest zachowanie w ramach określonych ról oraz motywacje. Grupa pierwotna ma ogromny wpływ na przyjmowanie przez jednostkę ogólnego stylu życia, odgrywanie ról życiowych czy sposób postępowania. Grupa pierwotna ma także przemożny wpływ na emocje i uczucia człowieka, ponieważ stany emocjonalne są zależne od tego, jak kształtują się jego kontakty z osobami dla niego ważnymi ${ }^{34}$.

Wpływ grupy na jednostkę zależy od dynamiki grupy, czyli procesów w niej zachodzących. Bardziej jest on widoczny w grupach wtórnych, dość licznych, umiejscowionych w określonej strukturze. Grupy te posiadają przywódcę. Więzi społeczne w grupie prowadzonej i nadzorowanej przez przywódcę są formalne, ukierunkowane na wspólnotę bardziej zorganizowaną, zmierzającą do realizacji określonych celów. Działaniom członków grupy towarzyszy myśl o osiągnięciu pewnych korzyści. Bardziej liczy się orientacja na efekty niż dbałość o osobiste, emocjonalne związki i zależności.

Przywództwo w grupie zmierza do realizacji konkretnych zadań wyznaczonych przez system władzy. Dąży ono do kierowania innymi osobami w grupie oraz koordynowania ich działań dla osiągnięcia założonego celu. W literaturze anglojęzycznej mówi się o przywództwie zadaniowym i socjoemocjonalnym, a w polskiej częściej o przywództwie formalnym lub nieformalnym. Przywódca zadaniowy poprzez swe działanie niekiedy wywołuje napięcia, które zazwyczaj są czymś oczywistym w dużej zbiorowości ludzkiej. Wówczas istotną rolę pełni przywódca socjoemocjonalny, który „rozładowuje napięcie” poprzez dowcip, żart, dość swobodny komentarz w konkretnej sytuacji. Zdarza się, że czasami doświadczony przywódca odgrywa obie te role. Pełnienie funkcji szefa nie przeszkadza mu jednocześnie łagodzić napięcia powstałego w grupie i niwelować nagromadzonych złych emocji u jej członków ${ }^{35}$.

Podejmowanie decyzji w grupie jest procesem dość trudnym, często stresującym zarówno przywódcę, jak i członków grupy. Jest to wybór wspólny, oparty na racjonalnych przesłankach, często uzależniony od 
większości głosów. Stąd decyzje grupowe są bardziej zdecydowane i rozstrzygające niż decyzje jednostkowe.

Decyzja grupowa jest:

- ostrożniejsza, bo rozkłada odpowiedzialność na poszczególnych członków grupy, co jest wynikiem strachu przed popełnieniem błędu;

- członkowie grupy z reguły powstrzymują się przed krytykowaniem siebie nawzajem, co powoduje, iż grupa działa stanowczo i zdecydowanie ${ }^{36}$.

Podejmowanie decyzji polega na zbieraniu informacji, dokonywaniu analizy i oceny, a dopiero potem na wyborze decyzji, która ma być wprowadzana w życie. Jest działaniem podporządkowanym określonym celom oraz zakładanym korzyściom zespołowym.

Niezależnie od tego, czy grupy są pierwotne, czy wtórne różnią się między sobą tym, jak silne więzi łączą poszczególnych jej członków. Istotną rolę odgrywa tu solidarność i spoistość grupy. W grupach spójnych ludzie czują się bardziej bezpieczni, chętniej też przestrzegają obowiązujących w nich norm.

Na spójność grup i poczucie solidarności w grupie wpływają w szczególności:

- niewielkie rozmiary grup;

- podobieństwo sytuacji życiowej;

- poczucie zagrożenia z zewnątrz;

- wysoki wskaźnik aprobaty wobec tych, którzy przestrzegają norm;

- więzi emocjonalne, wynikające m.in. z poczucia docenienia;

- zauważanie podobieństw u siebie i u innych ${ }^{37}$.

Grupy tworzą określone ramy. Są dla ludzi grupami odniesienia, w znacznym stopniu ukierunkowują ich myśli i działania. Dotyczy to zwłaszcza grup, których jesteśmy członkami, lub takich, do których chcemy przynależeć. W rzeczywistości posługujemy się normami, wartościami, przekonaniami, symbolami kulturowymi należącymi do kilku grup naraz. Możemy być świadomi symboli, wartości i norm, którymi się posługujemy, a równocześnie odwoływać się do symboli innych grup, takich jak: rodzina, bliscy przyjaciele lub grupy, do których chcielibyśmy

36 J.H. Turner, Socjologia. Koncepcje i zastosowanie, dz. cyt., s. 96.

37 J.H. Turner, Socjologia. Koncepcje i zastosowanie, dz. cyt., s. 96-97. 
należeć. Dla zrozumienia własnego zachowania należałoby poznać konfigurację grup odniesienia, do których się odwołujemy. Mózg i szeroki wachlarz możliwości poznawczych pozwalają nam na przyjmowanie roli nawet osób nieobecnych oraz na wykorzystywanie naszych więzi (lub tylko pragnienia więzi) z nimi jako wskazówek określających nasze zachowanie. „Oddziaływanie grup odniesienia znacznie rozszerza istotę uczestniczenia w grupie oraz zwiększa różnorodność procesów, za pomocą których poszczególne grupy oddziałują na nas" ${ }^{38}$. Zdarzyć się może, że bardzo odległe grupy odniesienia mogą wywierać znacznie większy nacisk (w sensie określonego myślenia i zachowania) niż osoby fizycznie obecne ${ }^{39}$.

\section{Podsumowanie}

W dzisiejszym świecie nie sposób funkcjonować bez uczestnictwa w jakiejkolwiek grupie. Grupy są wszędzie, mniej lub bardziej sformalizowane. Zewsząd otaczają nas ludzie, którzy nas inspirują, pobudzają do działania w określonym kierunku, wyzwalają w nas potrzebę realizacji ukierunkowaną na sukces. Grupy w większym lub mniejszym stopniu stanowią dla nas oparcie, kształtują nasz stosunek do życia, poglądów, umożliwiają samorealizację. Przeciętnemu człowiekowi trudno jest wymienić grupy poza pierwotną - w których funkcjonuje, jest ich bowiem zbyt wiele. Ich cele nie zawsze muszą być podobne, bo najważniejsza jest więź, która łączy jej członków. Więź społeczna jest spoiwem, które krystalizuje daną społeczność ludzką, pozwala na nawiązywanie i utrzymywanie satysfakcjonujących kontaktów, wyzwala motywację do działania, pozwala na samoakceptację i wysoką samoocenę. Poprzez uczestnictwo w grupie jednostka może doskonalić się w określonym kierunku, rozwijać się: zawodowo, emocjonalnie, towarzysko, zdobywać nowe doświadczenia, stosować się do zasad i norm społecznych, wyznawać takie same wartości, poglądy, rozumieć symbole. Będąc w grupie, jednostka odczuwa pewną więź łączącą ją z innymi uczestnikami. Dzięki niej może czuć się rozumianą, akceptowaną, docenianą. Ona też prowadzi ją do wspólnych celów, które

38 J.H. Turner, Socjologia. Koncepcje i zastosowanie, dz. cyt., s. 97.

39 J.H. Turner, Socjologia. Koncepcje i zastosowanie, dz. cyt., s. 97. 
stają się także jej celami życiowymi. Jednostka wzrasta i socjalizuje się $\mathrm{w}$ grupie pierwotnej, potem wychodzi poza jej ramy, nie rezygnując jednak z uczestnictwa w tej grupie. Przenosi pewne wzory zachowań, nabywa szereg nowych w innych grupach, modyfikuje i wartościuje to, co jest dla niej istotne, gdyż łączy się z jej celami oraz celami konkretnej grupy, do której należy. Uczestniczenie w strukturze społecznej polega w większości na zajmowaniu pozycji w grupie, która zazwyczaj ulokowana jest w większej strukturze społecznej. Oznacza to, że grupy włączają nas w większe struktury społeczne, którymi są m.in.: organizacje, społeczność lokalna, instytucje, struktury kategoryzujące i system stratyfikacji.

\section{Abstrakt}

Ewolucja więzi spotecznych

Więzi społeczne to pojęcie w socjologii, które określa całokształt relacji społecznych osób, instytucji i środków kontroli społecznej, wiążących jednostki w grupy i kręgi społeczne, jednocześnie zapewniając im trwanie. Możemy przyjąć, że to relacje i zależności wiążące jednostkę z grupą bądź inną jednostką. Sięgają one najdawniejszych czasów, chociaż zdefiniowano je naukowo znacznie później i sformułowano szereg ich teorii, odnoszonych do ich powstawania, funkcjonalności, potrzeb i oczekiwań jednostki. Dla niektórych socjologów ważnym czynnikiem więzi, decydującym o istnieniu grupy, jest świadomość wspólnego stosunku do przedmiotów, symboli, wartości, norm czy osób. Więzi społeczne ujawniają się w grupie, ona je kształtuje, kreuje postawy i zachowania swych członków, poglądy i przekonania, wyznacza ramy określonego stylu życia. Więź powstała i podtrzymywana w grupie wyrasta na kanwie najistotniejszych potrzeb jednostki oraz potrzeb międzyludzkich. Uczestniczenie w strukturze społecznej polega przede wszystkim na zajmowaniu pozycji w grupie, która zazwyczaj ulokowana jest w większej strukturze społecznej. Oznacza to, że grupy włączają nas w większe struktury społeczne, którymi są m.in.: organizacje, społeczność lokalna, instytucje, struktury kategoryzujące i system stratyfikacji.

Słowa kluczowe: rodzina, grupa społeczna, więź społeczna, spójność grupy 


\section{Abstract}

\section{Evolution of social bonds}

Social bonds is a concept in sociology which defines the overall social relations of people, institutions and means of social control, binding individuals into social groups and social circles, while ensuring their duration. We can assume that these are relations and dependencies linking an individual with a group or another entity. They go back to the most ancient times, although they were scientifically defined much later and a number of their theories were formulated, related to their formation, functionality, needs and expectations of an individual. For some sociologists, an important factor in a bond that determines the existence of a group is the awareness of a common relationship to objects, symbols, values, norms or people. Social ties show up in the group. The group shapes them, creates the attitudes and behavior of its members, views and beliefs, establishes the framework for a specific lifestyle. The bond created and maintained in the group is based on the basis of the most essential needs of the individual and interpersonal needs. Participation in the social structure is mostly based on taking a position in a group that is usually located in a larger social structure. This means that groups include us in larger social structures, such as organizations, local communities, institutions, categorizing structures and a system of stratification.

Keywords: family, social group, social bond, group cohesion

\section{Bibliografia}

Batko A., Społeczeństwo od A do Z, Wydawnictwo „Zamiast korepetycji”, Kraków 1997.

Kenrick D. T., Neuberg S. L., Cialdini R. B., Psychologia społeczna, Gdańskie Wydawnictwo Psychologiczne, Gdańsk 2001.

Olechnicki K., Załęcki P., Stownik socjologiczny, Wydawnictwo Graffiti вC,

Toruń 2004.

Oyster C. K., Grupy, Zysk i S-Ka Wydawnictwo, Poznań 2000. 
Pachcholski M., Stownikpojęć socjologicznych, Wydawnictwo Akademii Ekonomicznej w Krakowie, Kraków 1997.

Szacka B., Wprowadzenie do socjologii, Oficyna Naukowa, Warszawa 2008. Szacki J., Historia myśli socjologicznej, Państwowe Wydawnictwo Naukowe, Warszawa 2002.

Szendlak T., Socjologia rodziny, Wydawnictwo Naukowe Pwn, Warszawa 2010.

Sztompka P., Socjologia, Wydawnictwo Znak, Warszawa 2004.

Turner J.H., Socjologia. Koncepcje i zastosowanie, Zysk i S-ka Wydawnictwo, Poznań 1998. 